Diklabio: Jurnal Pendidikan dan Pembelajaran Biologi, 5 (2), 217-225 (2021)

Diklabio: Jurnal Pendidikan dan Pembelajaran Biologi

Journal homepage: https://ejournal.unib.ac.id/index.php/jppb

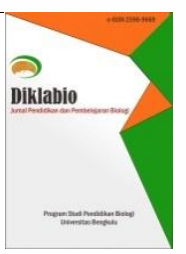

\title{
Pengembangan LKPD pada Materi Protista Kelas X SMA Berdasarkan Keanekaragaman Mikroalga di Sungai Bengkenang
}

\author{
Silvia Rani ${ }^{1 *}$, Dewi Jumiarni ${ }^{1}$, Aceng Ruyani ${ }^{1}$, Abdul Rahman ${ }^{1}$, Kasrina Kasrina ${ }^{1}$ \\ ${ }^{1}$ Program Studi S-1 Pendidikan Biologi, Fakultas Keguruan dan Ilmu Pendidikan, Universitas \\ Bengkulu, Indonesia
}

*Email: ranisilvia485@gmail.com

\begin{tabular}{|c|c|}
\hline Info Artikel & Abstrak \\
\hline $\begin{array}{l}\text { Diterima: } 21 \text { Oktober } 2020 \\
\text { Direvisi: } 18 \text { Oktober } 2021 \\
\text { Diterima } \\
\text { untuk diterbitkan: } 27 \text { Oktober } \\
2021\end{array}$ & $\begin{array}{l}\text { Penelitian ini bertujuan untuk menguji kelayakan Lembar Kerja } \\
\text { Peserta Didik (LKPD) yang dikembangkan berdasarkan } \\
\text { keanekaragaman mikroalga di Sungai Bengkenang. Metode } \\
\text { penelitian yang digunakan adalah metode Penelitian dan } \\
\text { Pengembangan (Research and Development) menurut }\end{array}$ \\
\hline $\begin{array}{l}\text { Keywords: } \\
\text { LKPD } \\
\text { Mikroalga } \\
\text { Sungai Bengkenang }\end{array}$ & $\begin{array}{l}\text { Sugiyono (2010) yang terbatas pada tujuh tahap yaitu potensi } \\
\text { dan masalah, pengumpulan data, desain produk, validasi } \\
\text { desain, revisi desain, uji keterbacaan, dan revisi produk. Teknik } \\
\text { pengumpulan data pada penelitian ini menggunakan } \\
\text { wawancara, angket, sampling, dan studi pustaka. Analisis data } \\
\text { dilakukan secara deskriptif kualitatif. Hasil rerata persentase } \\
\text { validasi oleh validator ahli materi, ahli bahan ajar, dan ahli } \\
\text { praktisi LKPD yang dikembangkan sebesar } 95,80 \% \text { dengan } \\
\text { kriteria sangat valid dengan keputusan uji sangat layak dan } \\
\text { rerata persentase uji keterbacaan LKPD oleh peserta didik } \\
\text { sebesar 87,36\% dengan kriteria sangat layak. Berdasarkan } \\
\text { hasil validasi dan uji keterbacaan tersebut dapat disimpulkan } \\
\text { bahwa LKPD Protista Mirip Tumbuhan yang telah } \\
\text { dikembangkan sangat layak digunakan untuk uji coba pada } \\
\text { mata pelajaran Biologi pada materi Protista. }\end{array}$ \\
\hline
\end{tabular}

(C) 2021 Universitas Bengkulu. This is an open-access article under the CC-BY license (https://creativecommons.org/licenses/by/4.0)

\section{PENDAHULUAN}

Pendidikan merupakan proses interaksi manusia dengan lingkungannya secara sadar dan terencana untuk mengembangkan potensi diri (Ahmadi, 2016). Manusia yang telah mendapat pendidikan akan memiliki kemampuan dan kompetensi yang lebih baik dibandingkan dengan yang tidak mendapat pendidikan (Kompri, 2015). Penyelenggara pendidikan dilakukan secara terintegrasi antara pendidik, peserta didik, lingkungan dan pendidikan. Peran pendidikan bagi manusia adalah mengangkat martabat, derajat, kecerdasan, moral, dan dapat menjadikan manusia tersebut lebih bermanfaat dari manusia lain (Yamin, 2012). UU No. 20 tahun 2003 pasal 3 tentang Sistem Pendidikan Nasional menyatakan bahwa fungsi pendidikan nasional adalah mengembangkan 
kemampuan dan membentuk watak serta peradaban bangsa yang bermartabat dalam rangka mencerdaskan kehidupan bangsa. Sedangkan tujuan pendidikan nasional adalah untuk mengembangkan potensi peserta didik agar menjadi manusia yang beriman dan bertakwa kepada Tuhan Yang Maha Esa, berakhlak mulia, sehat, berilmu, cakap, kreatif, mandiri, dan menjadi warga negara yang demokratis, bertanggung jawab, berkualitas, dan berkarakter.

Setiap lembaga pendidikan diharapkan lebih fokus pada pengembangan potensi peserta didik yang berkaitan dengan karakter serta berorientasi pada aspek sikap dan tingkah laku (afektif). Namun, implementasi di lapangan menunjukkan bahwa masih banyak pembelajaran yang hanya berorientasi pada aspek kecerdasan (kognitif) dan kecakapan hidup (psikomotorik), sehingga sebagian besar peserta didik hanya mementingkan hasil belajar tanpa memperhatikan aspek sikap dan tingkah laku. Hal ini yang menjadi alasan pemerintah untuk mengembangkan pendidikan yang berkarakter dalam dunia pendidikan.

Salah satu kebijakan pemerintah untuk mencapai tujuan pendidikan nasional adalah dengan menyusun kurikulum baru yaitu Kurikulum 2013. Pemerintah berharap dengan adanya perubahan kurikulum ini dapat mengakibatkan terjadinya revolusi mental dari peserta didik. Kurikulum 2013 yang diterapkan saat ini diharapkan dapat menghasilkan generasi penerus bangsa yang produktif, kreatif, inovatif, dan berkarakter. Menurut Abidin (2014), kurikulum 2013 merupakan pembelajaran yang menuntut peserta didik untuk merangkai pengalaman belajar dengan bekerja secara ilmiah. Oleh sebab itu, pembelajaran dalam konteks kurikulum 2013 dilakukan dengan berlandaskan pada pendekatan ilmiah (scientific approach). Pendekatan ilmiah (scientific approach) menurut kamus Besar Bahasa Indonesia (KBBI) adalah penggunaan teori suatu bidang ilmu untuk menyelesaikan suatu masalah. Sedangkan menurut Hosnan (2014), pendekatan ilmiah adalah perspektif (sudut pandang) teori yang dapat digunakan sebagai landasan dalam memilih model, metode, maupun teknik pembelajaran.

Upaya mewujudkan tujuan pendidikan memerlukan tenaga pendidik yang professional. Tenaga pendidik dituntut untuk terampil dan kreatif dalam mengelola pembelajaran. Salah satu wujud profesionalitas yang diharapkan dari pendidik adalah mampu mengembangkan bahan ajar yang inovatif. Contoh bentuk bahan ajar yang dapat dikembangkan oleh pendidik yaitu Lembar Kerja Peserta Didik (LKPD). LKPD merupakan suatu bahan ajar cetak yang berisi materi, ringkasan, dan tugas yang mengacu pada kompetensi dasar (Prastowo, 2015). Materi pada LKPD memiliki karakteristik yaitu ringkas dan padat. Fungsi LKPD dalam pembelajaran yaitu membentuk interaksi yang efektif antara peserta didik dengan pendidik. LKPD juga mempermudah peserta didik untuk memahami materi yang diberikan. LKPD disiapkan dengan cermat sebelum digunakan dalam proses pembelajaran, lembar kerja harus memenuhi kriteria yang berkaitan dengan pencapaian sebuah kompetensi dasar oleh peserta didik (Majid, 2009).

Berdasarkan hasil wawancara yang telah dilakukan menunjukkan bahwa kegiatan pembelajaran belum memanfaatkan lingkungan sebagai sumber belajar. Pembelajaran masih menggunakan LKPD dari penerbit nasional, padahal pemanfaatan lingkungan sekitar sebagai sumber belajar dapat membuat pembelajaran menjadi lebih kontekstual sehingga pembelajaran menjadi lebih menarik. Pembelajaran yang menarik serta kontekstual terbukti dapat meningkatkan pengetahuan bagi peserta didik (Kadir, 2013). Menurut Ruswandi dan Badruddin (2008), pemanfaatan lingkungan sebagai media pembelajaran akan menjadikan proses belajar mengajar menjadi lebih bermakna, karena peserta didik dihadapkan pada peristiwa dan keadaan yang sebenarnya. Sehingga pengetahuan yang dipelajari peserta didik menjadi lebih nyata dan faktual.

Salah satu kompetensi dasar pada mata pelajaran biologi adalah KD 3.6 tentang mengelompokkan Protista berdasarkan ciri-ciri kelas dan mengaitkan peranannya dalam kehidupan (Permendikbud, 2018). Protista umumnya merupakan organisme bersel satu, namun ada juga yang ditemukan dalam bentuk koloni dan bersel banyak. Protista dapat dibedakan menjadi tiga kelompok yaitu Protista mirip hewan (Protozoa), Protista mirip tumbuhan (Algae), dan Protista mirip jamur (Anshori, 2009). Protista merupakan bagian dari ilmu biologi yang memiliki cakupan materi yang cukup luas, sehingga akan sulit dipahami oleh peserta didik jika hanya belajar dengan membaca 
buku. Pembelajaran dengan menggunakan LKPD dengan materi yang kontekstual akan membantu peserta didik dalam memahami materi Protista karena peserta didik akan mengamati langsung Protista yang sedang dipelajari. Salah satu anggota Protista mirip tumbuhan disebut dengan mikroalga. Mikroalga adalah organisme berukuran sangat kecil dengan diameter antara 3-30 nanometer, yang dapat ditemukan di seluruh wilayah perairan air tawar maupun air laut. Mikroalga mempunyai bentuk dan warna yang beranekaragam. Keanekaragaman mikroalga merupakan salah satu potensi sumber belajar berbasis lingkungan yang dapat dikembangkan menjadi bahan ajar seperti lembar kerja peserta didik (LKPD).

Berdasarkan hal tersebut diperlukan pengembangkan LKPD berdasarkan keanekaragaman mikroalga di lingkungan sekitar untuk pembelajaran Biologi di SMA khususnya pada materi Protista. Peneliti tertarik memilih mikroalga sebagai objek studi karena mikroalga mudah ditemukan di lingkungan peserta didik seperti kolam, sungai, danau, laut, dan daerah perairan lainnya. Sehingga dengan adanya LKPD yang dikembangkan ini dapat meningkatkan motivasi dan membantu peserta didik untuk lebih memahami materi Protista.

\section{METODE}

Jenis penelitian yang digunakan dalam penelitian ini adalah Penelitian dan Pengembangan atau Reseach and Dovelopment (R \& D) modifikasi Sugiyono (2010) yang terdiri dari 7 tahap yaitu 1) Potensi dan masalah, 2) Pengumpulan data, 3) Desain produk, 4) Validasi desain, 5) Revisi desain, 6) Uji keterbacaan, dan 7) Revisi produk. Subjek pada penelitian adalah peserta didik kelas X IPA 1 SMAN 8 Kota Bengkulu pada tahun ajaran 2019/2020. Objek pada penelitian ini yaitu LKPD materi Protista berdasarkan keanekaragaman mikroalga di daerah aliran Sungai Bengkenang. Teknik pengumpulan data pada penelitian ini yaitu wawancara, angket, dan studi pustaka. Data hasil validasi dan uji keterbacaan LKPD merupakan data kuantitatif yang diubah menjadi data kualitatif, kemudian dianalisis secara deskriptif kualitatif. Skor yang didapat dari hasil lembar validasi dan uji keterbacaan dianalisis dengan rumus :

$$
\text { Presentase }=\frac{\text { Jumlah skor lembar validitas }}{\text { Skor maksimal }} \times 100 \%
$$

(Riduwan, 2015).

Hasil analisis data yang berupa presentase tersebut kemudian diinterpretasikan pada Tabel 1.

Tabel 1

Kriteria Penilaian Hasil Validasi dan Uji Keterbacaan

\begin{tabular}{lll}
\hline \multicolumn{1}{c}{ Skala Nilai } & \multicolumn{1}{c}{ Keterangan } & \multicolumn{1}{c}{ Keputusan Uji } \\
\hline $86 \%-100 \%$ & Sangat Valid & Sangat layak dan tidak revisi jika mencapai 100\% \\
$71 \%-85 \%$ & Valid & Layak namun tetap dilakukan revisi kecil \\
$56 \%-70 \%$ & Cukup Valid & Cukup layak dan perlu revisi besar \\
$41 \%-55 \%$ & Kurang Valid & Kurang layak dan perlu revisi besar \\
$25 \%-40 \%$ & Sangat kurang valid & Tidak layak dan perlu revisi besar \\
\hline
\end{tabular}

(Akbar, 2013).

\section{HASIL DAN PEMBAHASAN}

Pengembangan Lembar Kerja Peserta Didik (LKPD) pada penelitian ini menggunakan metode Research and Development Borg dan Gall (1989) yang dimodifikasi oleh Sugiyono (2010). Penelitian Research and Development yang telah dilakukan terdiri dari 7 tahapan, berikut merupakan hasil dari setiap tahapan yang telah dilakukan dalam pengembangan LKPD:

\section{Potensi dan Masalah}

Analisis kebutuhan awal dilakukan dengan menganalisis Kompetensi Dasar pada mata pelajaran Biologi di SMA dan melakukan wawancara dengan guru Biologi di SMAN 8 Kota Bengkulu. Berdasarkan analisis Kompetensi Dasar mata pelajaran Biologi ditemukan materi yang sesuai dengan LKPD keanekaragaman mikroalga yaitu pada KD 3.6 Mengelompokkan Protista 
berdasarkan ciri-ciri umum kelas dan mengaitkan perananya dalam kehidupan. Berdasarkan hasil wawancara dengan guru Biologi di SMAN 8 Kota Bengkulu diperoleh hasil sebagai berikut:

Sekolah masih menggunakan LKPD penerbit nasional sebagai bahan ajar yang digunakan dalam mengajarkan materi Protista.

1) Guru kesulitan saat mengajarkan materi Protista pada mata pelajaran Biologi karena LKPD penerbit nasional tidak berbasis lingkungan peserta didik sehingga pembelajaran menjadi kurang konstekstual.

2) LKPD mengenai Protista mirip tumbuhan sangat diperlukan dalam pembelajaran Biologi terutama berisi keanekaragaman Protista mirip tumbuhan lokal di Bengkulu.

3) Penggunaan LKPD dalam pembelajaran akan efektif karena berbasis lingkungan peserta didik sehingga pembelajaran menjadi lebih konstektual.

4) Guru Biologi mendukung pengembangan LKPD Protista mirip tumbuhan sebagai bahan ajar dalam mata pelajaran Biologi.

\section{Pengumpulan Data Keanekaragaman Mikroalga di Sungai Bengkenang}

Pengumpulan data pada penelitian ini dilakukan dengan mengamati karakteristik morfologi mikroalga yang ditemukan di Sungai Bengkenang. Hasil penelitian keanekaragaman mikroalga di Sungai Bengkenang pada 3 stasiun yaitu stasiun hulu (Desa Sukarami), stasiun tengah (Desa Durian Seginim) dan stasiun hilir (Desa Padang Burnai) memperoleh sebanyak 23 spesies yang terdiri dari 4 divisi yaitu 10 spesies Bacillariophyta, 4 spesies Cyanophyta, 6 spesies Chlorophyta, dan 3 spesies Euglenophyta. Data keanekaragaman mikroalga ini digunakan sebagai materi yang dikembangkan pada LKPD.

\section{Desain Produk Lembar Kerja Peserta Didik Protista Mirip Tumbuhan}

LKPD ini didesain menggunakan software Microsoft Word 2010 yang memiliki ukuran A4 (21 x 29,7 cm) dengan huruf (font) 11 Calibri dan spasi 1,15 serta terdiri dari 22 halaman. Berikut penjelasan mengenai komponen-komponen yang terdapat pada LKPD yang telah dibuat:

1) Sampul (cover) LKPD didesain semenarik mungkin menggunakan software Corel Draw. Sampul LKPD didominasi oleh warna biru, sampul depan berisi judul, logo Universitas Bengkulu, beberapa foto mikroalga yang ditemukan, identitas peserta didik, nama penulis, nama pembimbing utama dan pembimbing pendamping penulis, dan nama instansi penulis.

2) Halaman 1-4 berisi KD, indikator dan tujuan pembelajaran, serta pengenalan mikroalga, deskripsi sungai, foto stasiun pengambilan sampel, dan faktor fisika kimia lingkungan sungai.

3) Halaman 6-16 berisi foto mikroalga, klasifikasi mikroalga dan deskripsi mikroalga, serta tabel hasil identifikasi mikroalga di Sungai Bengkenang.

4) Halaman 17-21 berisi kegiatan peserta didik yang terdiri dari prosedur kerja, hasil pengamatan, dan pertanyaan.

\section{Validasi LKPD Protista Mirip Tumbuhan Sungai Bengkenang}

Validasi LKPD Protista Mirip Tumbuhan yang ditemukan di Sungai Bengkenang ini dilakukan oleh dua orang dosen ahli yaitu ahli media dan ahli materi serta satu orang guru sebagai ahli praktisi. Hal tersebut sesuai dengan pernyataan Ulviani, dkk (2017) yang mengemukakan untuk menghasilkan bahan ajar LKS yang layak atau valid untuk digunakan dilakukan validasi oleh dua dosen ahli yaitu ahli bahan ajar dan ahli materi serta oleh seorang guru Biologi SMA. Hasil validasi oleh validator materi dan ahli praktisi diperoleh persentase sebesar 97,37\% dengan kriteria sangat valid. Terdapat dua aspek yang divalidasi oleh ahli materi dan ahli praktisi yaitu aspek materi dan aspek kebahasaan. Persentase validasi oleh validator media diperoleh persentase sebesar 92,65\% dengan kriteria sangat valid. Adapun hasil validasi tersebut dapat dilihat pada Tabel 2. 
Tabel 2

Hasil Validasi LKPD oleh Validator

\begin{tabular}{|c|c|c|c|c|c|c|}
\hline \multirow{2}{*}{ No } & \multirow{2}{*}{ Validator } & \multicolumn{2}{|c|}{ Penilaian } & \multirow{2}{*}{$\begin{array}{c}\text { Skor } \\
\text { Maksimal }\end{array}$} & \multirow{2}{*}{ Presentase } & \multirow{2}{*}{ Kriteria } \\
\hline & & Aspek & Skor & & & \\
\hline \multirow{2}{*}{1} & \multirow{2}{*}{$\begin{array}{l}\text { Validator I } \\
\text { (Ahli Materi) }\end{array}$} & Materi & 47 & 48 & \multirow{2}{*}{$97,37 \%$} & \multirow{2}{*}{ Sangat valid } \\
\hline & & Kebahasaan & 27 & 28 & & \\
\hline 2 & $\begin{array}{l}\text { Validator II } \\
\text { (Ahli Media) }\end{array}$ & Media Ajar & 63 & 68 & $92,65 \%$ & Sangat valid \\
\hline \multirow{2}{*}{3} & Validator III & Materi & 47 & 48 & \multirow{2}{*}{$97,37 \%$} & \multirow{2}{*}{ Sangat valid } \\
\hline & (Ahli Praktisi ) & Kebahasaan & 27 & 28 & & \\
\hline & & Rata-Rata & & & $95,80 \%$ & Sangat Valid \\
\hline
\end{tabular}

Berdasarkan hasil tersebut didapat rerata persentase validasi oleh ketiga validator sebesar 95,80 \% dengan kriteria sangat valid dan keputusan uji sangat layak. Hasil yang sama juga di laporkan oleh Yani, dkk (2020) yang mengembangkan LKPD SMA berdasarkan keragaman tanaman obat masyarakat Desa Pondok Panjang Muko-muko memperoleh hasil validasi dengan kriteria sangat layak. Penelitian Pratama dan Saregar (2019) yang melaporkan bahwa pengembangan lembar kerja peserta didik (LKPD) berbasis Scaffolding untuk melatih pemahaman konsep dinilai sangat layak berdasarkan hasil validasi dari validator. Kemudian, Utomo (2018) yang mengembangkan LKPD berbasis komik untuk meningkatkan literasi ekonomi peserta didik yang memperoleh hasil validasi dengan kriteria sangat layak. Persentase validasi yang diperoleh menunjukkan keputusan uji yaitu sangat layak tetapi perlu dilakukan revisi berdasarkan saran dan komentar yang diberikan oleh ketiga validator.

\section{Revisi Desain LKPD Protista Mirip Tumbuhan Sungai Bengkenang}

Revisi desain LKPD Protista mirip tumbuhan yang ditemukan disungai bengkenang ini dilakukan berdasarkan saran dan komentar yang diberikan oleh ketiga validator. Adapun revisi yang dilakukan pada LKPD dapat dilihat pada Tabel 3.

\section{Tabel 3}

Perbedaan LKPD Sebelum dan Setelah Revisi Desain Berdasarkan Analisis Hasil Validasi

\begin{tabular}{|c|c|c|c|}
\hline No & LKPD Sebelum Revisi & LKPD Sesudah Revisi & Keterangan \\
\hline 1 & 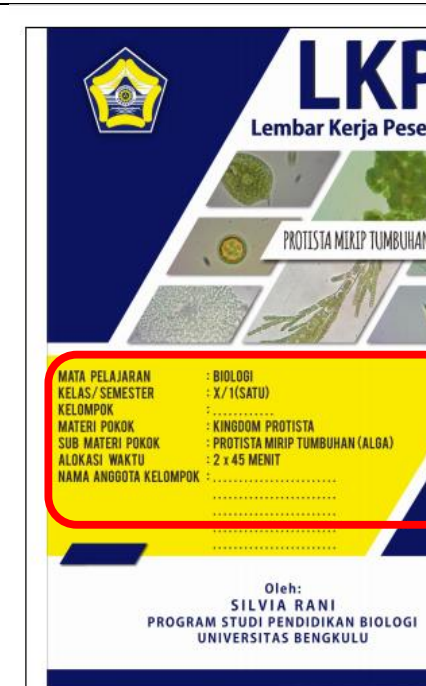 & 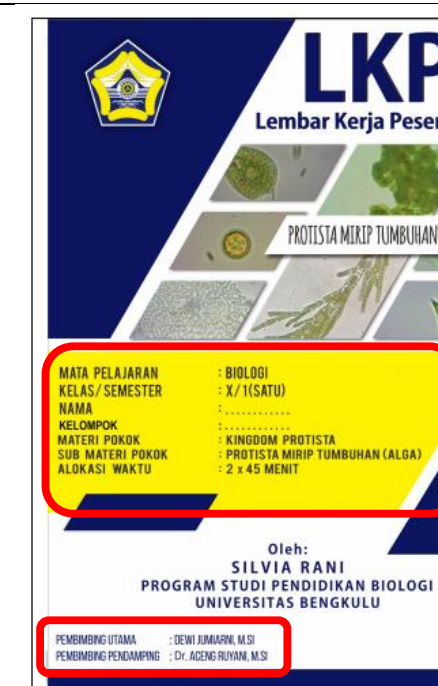 & $\begin{array}{l}\text { Cover atau sampul LKPD } \\
\text { yang awalnya tidak berisi } \\
\text { nama pembimbing utama } \\
\text { dan pembimbing } \\
\text { pendamping penulis } \\
\text { menjadi berisi nama } \\
\text { pembimbing utama dan } \\
\text { pembimbing pendamping } \\
\text { penulis. Bagian identitas } \\
\text { peserta didik pada sampul } \\
\text { yang awalnya ditujukan } \\
\text { untuk kelompok menjadi } \\
\text { ditujukan untuk individu }\end{array}$ \\
\hline
\end{tabular}


2.

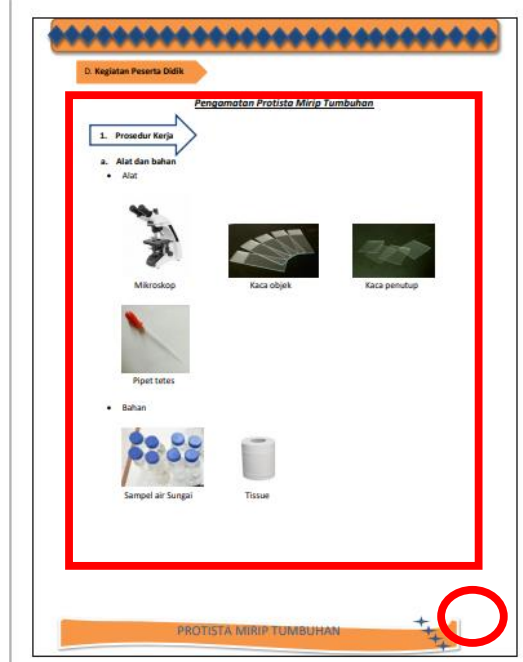

3.

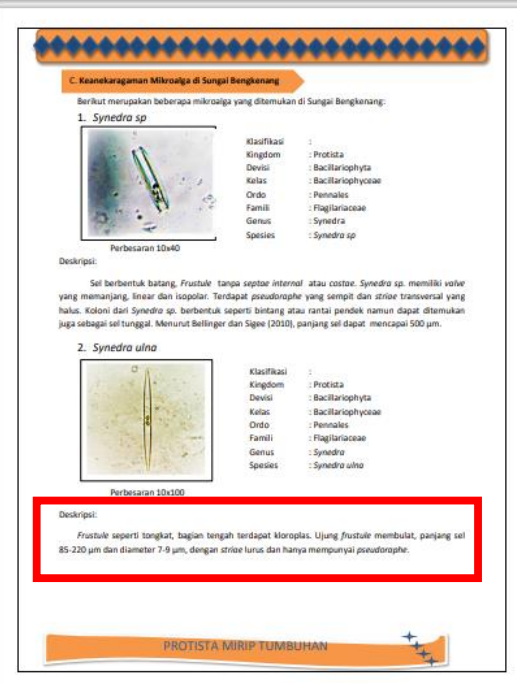

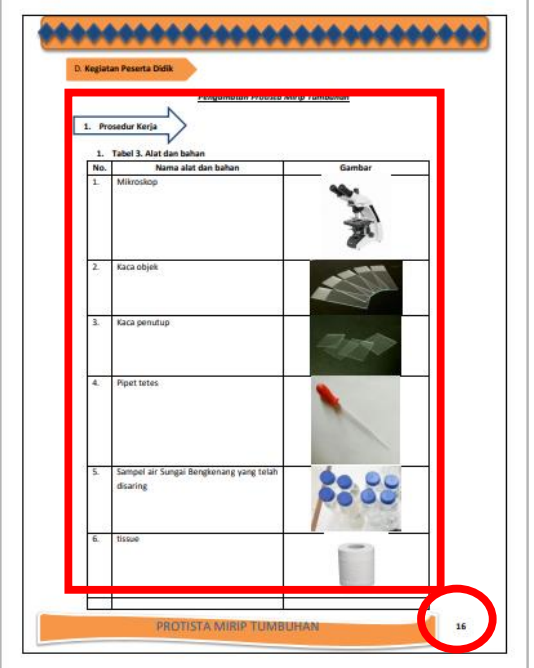

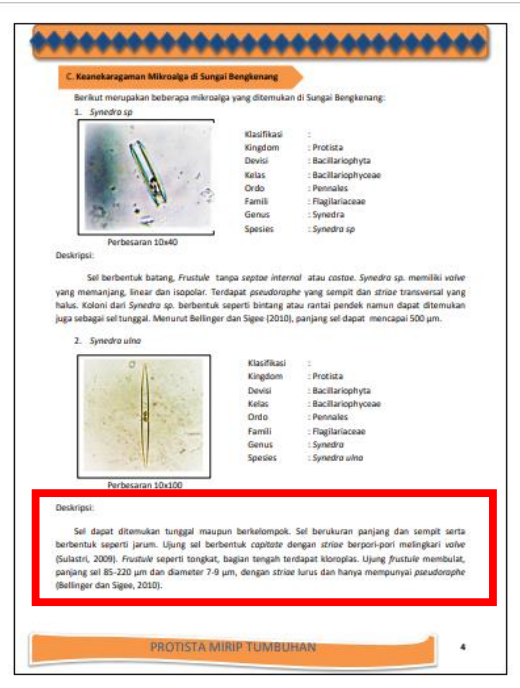

Bagian alat bahan pada LKPD yang awalnya tidak dimuat dalam tabel menjadi dimuat dalam tabel agar menjadi lebih rapi. LKPD yang awalnya tidak memiliki nomor halaman menjadi memiliki nomor halaman

Sumber referensi pada bagian deskripsi mikroalga yang awalnya hanya menggunakan Bellinger dan sigee (2010) menjadi ditambah sumber Sulastri (2009).

\section{Uji Keterbacaan LKPD Protista Mirip Tumbuhan}

Uji keterbacaan LKPD Protista mirip tumbuhan dilakukan terhadap 15 orang peserta didik di kelas X IPA 1 SMA 8 Kota Bengkulu. Adapun aspek yang dinilai pada uji keterbacaan ini terdiri dari 3 komponen (aspek), yaitu komponen penyajian materi, bahasa, dan tampilan. Hasil uji keterbacaan LKPD yang dikembangkan dapat dilihat pada Tabel 4.

\section{Tabel 4}

Hasil Uji Keterbacaan LKPD oleh Peserta Didik

\begin{tabular}{lllcccc}
\hline No & Komponen yang Dinilai & $\begin{array}{c}\text { Jumlah } \\
\text { Responden }\end{array}$ & $\begin{array}{c}\text { Skor } \\
\text { Akhir }\end{array}$ & $\begin{array}{c}\text { Skor } \\
\text { Maksimal }\end{array}$ & Persentase & Kriteria \\
\hline 1. & Penyajian Materi & 15 & 418 & 480 & $87,08 \%$ & $\begin{array}{l}\text { Sangat } \\
\text { Layak }\end{array}$ \\
2 & Kebahasaan & 15 & 261 & 300 & $87 \%$ & $\begin{array}{l}\text { Sangat } \\
\text { Layak }\end{array}$ \\
3. & Tampilan & 15 & 264 & 300 & $88 \%$ & $\begin{array}{l}\text { Sangat } \\
\text { Layak }\end{array}$ \\
\hline & & & & $87,36 \%$ & $\begin{array}{l}\text { Sangat } \\
\text { Layak }\end{array}$ \\
\hline
\end{tabular}

Berdasarkan Tabel 4 diketahui bahwa nilai rata-rata persentase hasil uji keterbacaan sebesar $87,36 \%$ dan kriteria sangat layak. Pada uji keterbacaan ini, komponen yang memperoleh persentase tertinggi yaitu komponen tampilan dengan persentase $88 \%$ dan kriteria sangat layak. Komponen penyajian materi memperoleh persentase sebesar $87,08 \%$ dengan kriteria sangat layak dan 
komponen kebahasaan memperoleh persentase $87 \%$ dengan kriteria sangat layak. Komponen tampilan memiliki persentasi hasil yang paling tinggi namun perlu adanya perbaikan kontras warna pada gambar sehingga gambar sel mikroalga menjadi lebih jelas. Komponen dengan persentasi tertinggi selanjutnya yaitu penyajian materi, perbaikan yang perlu dilakukan pada bagian komponen ini yaitu penyampaian materi dibuat menjadi lebih singkat dan mudah dipahami oleh peserta didik serta menambah materi-materi pengantar yang dapat membantu peserta didik untuk lebih memahami isi LKPD. Komponen selanjutnya yaitu kebahasaan yang memerlukan perbaikan pada bagian penggunaan istilah-istilah yang masih cukup sulit untuk dipahami oleh peserta didik.

Hasil yang sama dilaporkan oleh Uniati, dkk (2019) yang memperoleh hasil uji keterbacaan LKPD materi Keanekaragaman Hayati oleh 15 peserta didik kelas X SMA dengan kategori sangat layak. Penelitian Anggraini, dkk (2016) juga melaporkan hasil uji keterbacaan LKPD Berbasis learning cycle 7E materi sistem sirkulasi pada manusia untuk kelas XI SMA dengan kategori sangat layak. Kemudian Dermawati, dkk (2019), yang mengembangkan lembar kerja peserta didik (LKPD) berbasis lingkungan yang memperoleh hasil uji coba produk dengan kriteria sangat layak. Dengan hasil uji kelayakan tersebut maka LKPD Protista mirip tumbuhan yang telah dibuat sangat layak digunakan untuk uji coba pemakaian dalam mata pelajaran Biologi pada materi Kingdom Protista. Hal ini sesuai dengan pernyataan Akbar (2013) yang menyatakan bahwa media pembelajaran dapat dikatakan sangat layak bila rata-rata persentase dari angket validasi ahli media, ahli materi dan uji keterbacaan diatas $86 \%$.

\section{Revisi Produk}

Beberapa saran yang disampaikan peserta didik untuk memperbaiki LKPD menjadi lebih baik lagi. Sehingga revisi produk dilakukan berdasarkan saran dan komentar yang diberikan peserta didik. Adapun revisi yang telah dilakukan yaitu perbaiki kontras warna pada gambar dan menambah tempat jawaban untuk membuat grafik pada temuan penelitian. Memperbaiki kontras warna pada gambar dapat membuat gambar mikroalga menjadi lebih jelas sehingga lebih mudah untuk diamati. Hal tersebut sejalan dengan pernyataan Suharnan (2005) yang menjelaskan bahwa dalam sebuah buku atau bahan ajar dikatakan bahwa gambar dapat meningkatkan minat baca karena dengan gambar dapat membantu pembaca berimajinasi. Imajinasi dapat membantu seseorang meningkatkan kinerja ingatannya. Selanjutnya, penambahan tempat jawaban untuk membuat grafik membuat peserta didik dapat menjawab pertanyaan langsung pada LKPD tanpa harus menyiapkan kertas jawaban sendiri.

Kelebihan dari LKPD Protista mirip tumbuhan yang dikembangkan terletak pada materi yang disajikan berbasis lingkungan peserta didik sehingga pembelajaran menjadi lebih bermakna, hal ini sejalan dengan pendapat Ruswandi dan Badruddin (2008) yang menjelaskan bahwa pemanfaatan lingkungan sebagai media pembelajaran akan menjadikan proses belajar mengajar menjadi lebih bermakna, karena peserta didik dihadapkan pada peristiwa dan keadaan yang sebenarnya secara alami. Sehingga pengetahuan yang dipelajari peserta didik menjadi lebih nyata, lebih faktual, dan kebenarannya lebih dapat dipertanggungjawabkan. Penggunaan warna dan gambar pada LKPD juga dapat menarik minat peserta didik untuk mempelajarinya.

\section{KESIMPULAN}

LKPD Protista Mirip Tumbuhan yang telah dikembangkan sangat layak digunakan untuk uji coba pada mata pelajaran Biologi khususnya materi Kingdom Protista yang dapat dilihat berdasarkan rerata persentase validasi oleh validator ahli materi, ahli bahan ajar dan ahli praktisi sebesar 95,80 \% dengan kriteria sangat valid dengan keputusan uji sangat layak dan rerata persentase uji keterbacaan oleh peserta didik sebesar 87,36 \% dengan kriteria sangat layak.

Penelitian pengembangan LKPD Protista Mirip Tumbuhan yang hanya sampai tahap ke 7 sebaiknya dilanjutkan oleh peneliti selanjutnya hingga tahap ke 10 atau dilakukan penelitian mengenai efektivitas penggunaan LKPD Protista Mirip Tumbuhan sebagai bahan ajar dalam mata pelajaran Biologi di SMA. 


\section{UCAPAN TERIMA KASIH}

Terimakasih kepada Kemenristekdikti yang telah mendanai penelitian ini melalui Hibah Penelitian Dasar No. 772/UN30.15/LT/2019.

\section{DAFTAR PUSTAKA}

Abidin. (2014). Desain Sistem Pembelajaran dalam Konteks Kurikulum. Bandung: Refika Aditama.

Ahmadi, D. (2016). Studi Minat Dan Motivasi Belajar Siswa Di Smk Negeri Rajapolah (Doctoral dissertation, Universitas Pendidikan Indonesia). Retrieved from http://repository.upi. $\mathrm{edu} / 26747 /$.

Akbar, S. (2013). Instrumen Perangkat Pembelajaran. Bandung: Remaja Rosdakarya.

Anggraini, W., Anwar, Y., \& Madang, K. (2016). Pengembangan lembar Kerja Peserta Didik (LKPD) Berbasis Learning Cycle 7E Materi Sistem Sirkulasi pada Manusia untuk Kelas XI SMA. Jurnal Pembelajaran Biologi, 3 (1), 49-57.

Anshori, M, \& Martono, D. (2009). Biologi 1: Untuk Sekolah menengah Atas (SMA)-Madrasah Aliyah (MA) Kelas X. Jakarta: Pusat Perbukuan Departemen Pendidikan Nasional.Hafshoh, S. (2017). Pengembangan Bahan Ajar Berupa LKS dengan Metode Inkuiri Terbimbing (Guided Inquiry) pada Pembelajaran IPA Materi Interaksi Makhluk Hidup dan Lingkungannya Kelas VII Semester Genap di MTS Negeri Kendal (Doctoral dissertation, UIN Walisongo). Retrieved from http://eprints.walisongo.ac.id/7847/.

Depdiknas. (2003). Undang-Undang RI No. 20 Tahun 2003 Tentang Sistem Pendidikan Nasional.

Dermawati, N., Suprapta, \& Muzakkir. (2019). Pengembangan Lembar Kerja Peserta Didik (LKPD) Berbasis Lingkungan. Jurnal Pendidikan Fisika, 7 (1), 74-78.

Hosnan, M. (2014). Pendekatan Saintifik dan Kontekstual dalam Pembelajaran Abad 21. Bogor: Ghalia Indonesia.

Kadir, A. (2013). Konsep pembelajaran kontekstual di sekolah. Dinamika ilmu, 13(1), 17-38. doi: 10.21093/di.v13i1.20

Kompri. (2015). Motivasi Pembelajaran Perspektif Guru dan Siswa. Bandung: PT Remaja Rosdakarya Offset.

Majid, A. (2009). Perencanaan Pembelajaran. Bandung: PT Remaja Rosda .

Peraturan Menteri Pendidikan dan Kebudayaan. (2018). Tentang Struktur Kurikulum 2013 SMA/MA. Jakarta: Kementerian Pendidikan dan Kebudayaan. Jakarta : Mendikbud.

Prastowo, A. (2015). Panduan Kreatif Membuat Bahan Ajar Inovatif. Yogyakarta: DIVA Press

Pratama, A.P., Saregar A. (2019). Pengembangan Lembar Kerja Peserta Didik (LKPD) Berbasis Scaffolding Untuk Melatih Pemahaman Konsep. Indonesian Journal Of Science and Mathematics Education, 02(1) (2019), 84-97. Doi: 10.24042/IJSME.v2I1.3975

Riduwan. (2015). Skala Pengukuran Variabel-Variabel Penelitian. Bandung: Alfabeta.

Ruswandi, U., \& Badruddin. (2008). Media Pembelajaran. Bandung: CV Insan Mandiri.

Sugiyono. (2010). Metode Penelitian Pendidikan Pendekatan Kuantitatif, Kualitatif dan R\&D. 
Bandung : Alfabeta.

Suharnan. (2005). Psikologi Kognitif. Surabaya: Srikandi.

Ulviani, Y., Kasrina, K., \& Idrus, I. (2017). Pengembangan LKS Berdasarkan Identifikasi Tumbuhan Paku Epifit pada Batang Kelapa Sawit. Diklabio: Jurnal Pendidikan dan Pembelajaran Biologi, 1(1), 105-112. doi: 10.33369/diklabio.1.1.105-112

Utomo, E.P. (2018). Pengembangan LKPD Berbasis Komik untuk Meningkatkan Literasi Ekonomi Peserta Didik. Jurnal Penelitian Pendidikan, 35(1), 1-9

Uniati, O., Jumiarni D., \& Yani, A. P. (2019). Pengembangan LKPD Berdasarkan Keragaman Jenis Tanaman Di Green Chemistry dan Kebun Biologi Universitas Bengkulu. Diklabio: Jurnal Pendidikan Dan Pembelajaran Biologi, 3(1), 17-24. doi 10.33369/diklabio 3.1.1724

Yamin, M. (2012). Desain Baru Pembelajaran konstruktivistik. Jakarta: Referensi.

Yani, A.P., Julianti, E.M., \& Irawati, S. (2020). Pengembangan LKPD SMA Berdasarkan Keragaman Tanaman Obat Masyarakat Desa Pondok Panjang Mukomuko. Diklabio: Jurnal Pendidikan Dan Pembelajaran Biologi, 4(1), 1-9. doi 10.33369/diklabio 4.1.1-9 